\title{
Anesthesiologists And The Risk for Suicidal Behaviour: A Note of Concern
}

\author{
By Usha Gurunathan
}

\begin{abstract}
Physicians may be as susceptible to depression and suicide as general population despite their seemingly healthier lifestyles. The author, an anesthesiologist, has been particularly concerned about the existence of suicidal behaviour amongst anesthesiologists, the specialist doctors with easy access to lethal and addictive drugs, and would like to raise an awareness about this issue.
\end{abstract}

\section{ABSTRACT}

Although physicians seem to have healthy lifestyles, they can be susceptible to the stress of the profession, resulting in substance abuse and depression that may culminate in suicide. Amongst the medical fields, anesthesiology has been considered as a stressful specialty due to the huge responsibility involved in safe care of patients through any surgery as well as the production pressure and time constraints in the work atmosphere. This burden, along with the advanced clinical skills and ready accessibility to potent drugs, increases the risk of addiction and suicide. This article summarises the results from various studies done so far on the factors contributing to the risk of suicide in physicians, in particular anesthesiologists, and discusses the issues associated with detection of the extent of the problem along with strategies to prevent further increase in the problem. It is intended to raise public awareness about this occupational hazard amongst trainees and consultants in this profession.

Leger med en tilsynelatende sunn livsførsel, kan være sårbare for profesjonsstresset, noe som kan resultere i stoffmisbruk og depresjon - ov videre føre til selvmordsatferd. Blant spesialistgrenene har anestesi blitt betraktet som spesielt stressende, grunnet det store ansvaret som forsvarlig pasientpleie ved enhver kirurgi krever, samt produksjonspress og tidsføringer i jobbsituasjonen. Denne byrden, i tillegg til de avanserte tekniske ferdighetene denne gruppen besitter og tilgjengeligheten av potente legemidler, $\varnothing$ ker risikoen for avhengighet og selvmord. Denne artikkelen oppsummerer resultatene fra ulike studier som har unders $\varnothing \mathrm{kt}$ de risikofaktorer som medvirker til legers selvmordsrisiko, særlig hos anestesileger. Artikkelen diskuterer hvorfor det er vanskelig å oppdage problemet og hvor utbredt det er, samt forbyggingsstrategiene. Artikkelen er ment som et innlegg for å mane til offentlig oppmerksomhet rundt de yrkesrisiko som omgir turnuskandidater og spesialister i denne profesjonen.

SUBMITTED: 21.07 .11 REVISED: $\quad 08.11 .11$ ACCEPTED: 08.11 .11

\section{Introduction}

Suicide has been described as a complex issue with several state-dependent and trait-dependent contributing factors (Hawton, et al., 2009). One of the pathways to suicide relates to the presence of stressful life events and the absence of social supports leading on to depressive and suicidal thoughts and to searching for the means to suicide resulting in the catastrophic event finally (Jenkins, et al., 2000). Physicians may be as susceptible to depression and suicide as general population despite their seemingly healthier lifestyles.

Higher suicide rates were observed among physicians than general population according to the studies from Norway and United States (U.S) (Aasland et al., 2011, Hem et al., 2005, Schernhammer et al., 2004, Aasland et al., 2001). The relative risk of suicide was found to be 1.1-3.4 amongst male doctors and 2.5-5.7 among female doctors compared to that of general population (Lindeman et al., 1996). In contrast, Meltzer and colleagues (2008), observed lower suicide mortality in male doctors compared to general population in England and Wales between 2001-2005.

The author, an anesthesiologist, has been particularly concerned about the existence of suicidal behaviour amongst anesthesiologists, the specialist doctors with easy access to lethal and addictive drugs, and would like to raise an awareness about this issue. In the following review, the author has attempted to discuss the factors leading to suicidal tendencies among anesthesiologists along with some strategies to prevent worsening of the problem. It is to be noted that these issues may not be exclusive to anesthesiologists and several of them may be applicable to medical community as a whole.

\section{Methods}

Literature search using Medline and Embase database was done using the medical subject headings "anesthesiology", "anaesthetist*", "suicide", "substance-related disorders", "stress", "psychological depression", "physician", terms connected through Boolean operators. The search was limited to papers from 1990-Oct. 2011 and to articles in English. This produced 127 hits. Of them, 21 were excluded as not being relevant. Forty-eight articles that included comments, personal communications, letters to editor, editorials and 20 articles that included case reports and case series were excluded. Thirteen were excluded as they were duplicated. Two articles dealt with nurse anesthesiologists. Of the remaining 23 articles, 14 dealt with studies on physicians and suicide, two of them being metaanalysis and systematic reviews on the same topic. Every article's reference list was searched to get further articles. This produced 20 articles on the main topic of interest including the remaining 12 from the above search. A document on "stress in anaesthetists" released by the Association of Anaesthetists of Great Britain and Ireland (AAGBI) was also included for discussion.

\section{Results}

The search did not identify many relevant studies specific to anesthesiologists. Several issues were common between anesthetists and doctors in general and this may be unavoidable. Most of the large-scale studies were outdated and many had methodological limitations. A large-scale cohort study by Alexander and colleagues (2000) on 80,453 doctors reported $45 \%$ higher risk of suicide among anesthesiologists compared to internal medicine physicians. They described substance abuse and suicide as "significant occupational hazards for anesthesiologists". 
In a later study on 223 doctors, it was observed that the suicide rate was higher among anesthesiologists, psychiatrists, community health doctors and general practitioners compared to general hospital doctors (Hawton et al., 2001). Lindfors and colleagues (2009) found a rate of $24.5 \%$ suicidality amongst all Finnish anesthesiologists. The findings from the studies pertaining to physicians and suicide are presented in Table 1 . Several factors contributing to suicide were identified.

\section{Substance abuse}

Substance abuse is a significant risk factor for suicide in the medical profession (Swanson et al., 2003; Schernhammer et al., 2004; Alexander et al., 2000). Suicide may even be the first presentation of this problem (Swanson et al., 2003). The field of anesthesia is more likely to be linked to drug abuse since anesthesiologists deal with potent addictive medications all the time and have an extensive knowledge about them (Greenwell, 2000). Opioids seem to be the most common drug of addiction among anesthesiologists (Bryson et al., 2008). The uniqueness of this specialty is that they administer most of the addictive drugs directly to the patient with minimal supervision and do not prescribe the drugs for someone else to administer (Thomas et al., 2006). There is a speculation that the access factor could be a major reason for physicians choosing this speciality (Weeks et al., 1993). Concern has been raised about the sensitization of the brain due to unintentional exposure to anesthetic agents in the operating room ambience along with the high job stress and the relative ease of accessing the drugs for personal use contributing to drug abuse among anesthesiologists (Gold et al., 2004). Apart from the access factor and environmental exposure, other factors like high stress and behavioral traits can also contribute to addiction (Bryson et al., 2011). Mental health issues and family problems were more common risk factors in Australia and New Zealand according to a survey (Fry et al., 2005). Booth and colleagues (2002) found the incidence of drug abuse to be $1.0 \%$ and $1.6 \%$ among faculty members and residents in 123 anesthesia departments in U.S. Schernhammer and colleagues (2004) observed that anesthesiologists, psychiatrists and emergency by drug abuse whereas Lutsky and colleagues (1994) concluded that anesthesiologists do not show higher overall rate of substance abuse compared to medicine and surgeons.

Alcohol and drug addiction is difficult to detect and treat since the affected individual may be effectively concealing the relevant signs and symptoms from the family or his work place. Usual presentation could be outside work place with minor offences or even major incidents such as suicide (Thomas et al., 2006). Physicians in general may be intentionally concealing the cause of death and underreport suicide of other colleagues due to social stigma (Swanson et al., 2003). Return to work in the same atmosphere relapse after a successful period of physicians seem to be the most affected for an anesthesiologist could result in

abstinence, especially if there is history of previous relapse or similar family history (Thomas et al., 2006). Reentry to practice should be carefully considered on an individual basis since there could be relapses even several years after treatment and recovery according to Bryson and colleagues (2008). Entry into lower risk specialties may be a solution for this issue (Collins et al., 2005).

\section{Stress related causes}

Stress is defined as mental, emotional or physical strain according to AAGBI (1997). Although it has been accepted that a certain amount of stress may be needed in the medical profession since it is a highly demanding field with high expectations and litigations, problems can occur when the stress exceeds the coping abilities. It can result in mental and physical disintegration (AAGBI, 1997). Stress along with inadequate coping mechanisms can lead to job dissatisfaction and impaired decision-making, ultimately resulting in suicide (Thomas et al., 2006). Stress can also lead to alcohol and drug abuse.

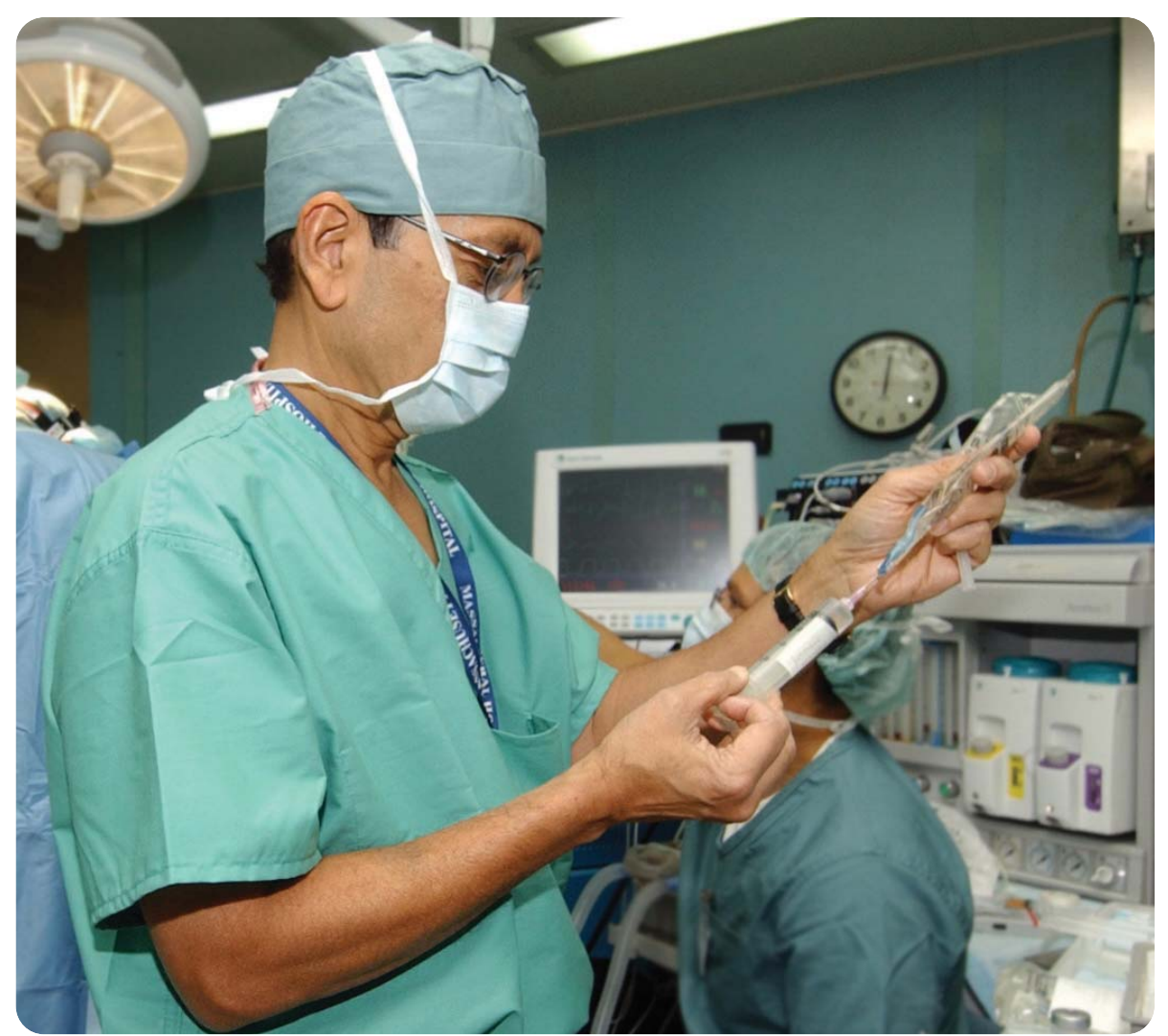


Table 1: Main findings of studies published on physicians and suicidial behavior between 1990-0ct 2011

\begin{tabular}{|c|c|c|c|c|}
\hline $\begin{array}{l}\text { Authors } \\
\text { (Publica- } \\
\text { tion year) }\end{array}$ & $\begin{array}{l}\text { Country and } \\
\text { Study Period }\end{array}$ & Data source & Study design & Main findings \\
\hline $\begin{array}{l}\text { Aasland et } \\
\text { al., (2011) }\end{array}$ & $\begin{array}{l}\text { Norway; } \\
\text { 1960-2000 }\end{array}$ & $\begin{array}{l}\text { Census data relating } \\
\text { to education from } \\
\text { Statistics Norway }\end{array}$ & $\begin{array}{l}\text { Data linked to data on } \\
14 \text { main causes of } \\
\text { death; Measure: MRR }\end{array}$ & $\begin{array}{l}\downarrow \text { all cause mortality for doctors from } 1960 \text { to } 2000 . \downarrow \text { mortality } \\
\text { in doctors compared to general population for all causes of } \\
\text { death except suicide. }\end{array}$ \\
\hline $\begin{array}{l}\text { Shanafelt } \\
\text { et al., } \\
(2011)\end{array}$ & U.S., 2008 & $\begin{array}{l}\text { Members of American } \\
\text { College of Surgeons }\end{array}$ & $\begin{array}{l}\text { Cross sectional survey; } \\
\text { questions on SI and use } \\
\text { of mental health resour- } \\
\text { ces along with screening } \\
\text { tool for depression and } \\
\text { assessments of burnout } \\
\text { and quality of life }\end{array}$ & $\begin{array}{l}\text { Response rate: } 31.7 \% \text {. Suicidal ideation } 1.5-3.0 \text { times more } \\
\text { common among surgeons }>45 \text { years. } 26 \% \text { with recent SI had } \\
\text { sought medical help while } 60 \% \text { were hesitant to seek help. } \\
1 \text { in } 16 \text { surgeons reported SI during the previous year. }\end{array}$ \\
\hline $\begin{array}{l}\text { Lindfors } \\
\text { et al., } \\
\text { (2009) }\end{array}$ & $\begin{array}{l}\text { Finland; } \\
\text { March 2004- } \\
\text { Oct } 2004\end{array}$ & $\begin{array}{l}\text { Finnish Medical } \\
\text { Register }\end{array}$ & $\begin{array}{l}\text { Cross sectional questi- } \\
\text { onnaire to all Finnish } \\
\text { anesthesiologists }\end{array}$ & $\begin{array}{l}22.4 \% \text { of all respondents reported having suicidal ideation and } \\
2.1 \% \text { had seriously planned suicide. }\end{array}$ \\
\hline $\begin{array}{l}\text { Dyrbye } \\
\text { et al., } \\
(2008)\end{array}$ & $\begin{array}{l}\text { U.S; } \\
\text { 2006-2007 }\end{array}$ & $\begin{array}{l}\text { Students were invited } \\
\text { from } 7 \text { medical schools }\end{array}$ & $\begin{array}{l}\text { Cross sectional } 2007 \text { and } \\
\text { longitudinal 2006-7 co- } \\
\text { hort study. Measure: } \\
\text { prevalence of suicidal } \\
\text { ideation in past year } \\
\text { and its relationship } \\
\text { to burnout, demograp- } \\
\text { hic characteristics and } \\
\text { quality of life }\end{array}$ & $\begin{array}{l}50 \% \text { of students experience burnout and } 10 \% \text { experience } \\
\text { suicidal ideation in medical school. Burnout associated with } \\
\text { increased chances of suicidal ideation later. }\end{array}$ \\
\hline $\begin{array}{l}\text { Meltzer et } \\
\text { al.,(2008) }\end{array}$ & $\begin{array}{l}\text { England, } \\
\text { Wales: } \\
\text { 2001-2005 }\end{array}$ & $\begin{array}{l}\text { Mortality data from } \\
\text { death registers: both } \\
\text { men and women aged } \\
\text { 20-64 years all } \\
\text { occupations }\end{array}$ & Measure: PMR, SMR & $\begin{array}{l}\text { Highest PMR (164) for health professionals followed by PMR } \\
\text { (133) agricultural workers; among physicians: suicide was } \\
\text { important cause of mortality as opposed to lower suicide } \\
\text { mortality than in general population. }\end{array}$ \\
\hline $\begin{array}{l}\text { Hawton } \\
\text { et al., } \\
(2004)\end{array}$ & $\begin{array}{l}\text { Eng.\& Wales; } \\
\text { Jan 1991- } \\
\text { Dec } 1993 .\end{array}$ & $\begin{array}{l}\text { List obtained from } \\
\text { the Office for National } \\
\text { Statistics }\end{array}$ & $\begin{array}{l}\text { Psychological autopsy } \\
\text { study of } 38 \text { working } \\
\text { doctors who died by } \\
\text { suicide }\end{array}$ & $\begin{array}{l}\text { Psychiatric illness in } 25 \text { of the doctors; depression \& drug/ } \\
\text { alcohol abuse - most common diagnosis. Most common } \\
\text { method of suicide: self poisoning. }\end{array}$ \\
\hline $\begin{array}{l}\text { Katz } \\
\text { et al., } \\
(2004)\end{array}$ & $\begin{array}{l}\text { U.S; } \\
1989-2001\end{array}$ & Physician master file & $\begin{array}{l}\text { Measure: crude morta- } \\
\text { lity rate and age specific } \\
\text { death rates among } \\
3 \text { special groups: anest- } \\
\text { hesiologists, internists } \\
\text { and all other physicians }\end{array}$ & $\begin{array}{l}\text { Anaesthesiologists had younger mean age at death than did } \\
\text { internists and all other physicians. No difference in age } \\
\text { specific mortality between three groups. }\end{array}$ \\
\hline $\begin{array}{l}\text { Tyssen } \\
\text { et al., } \\
(2004)\end{array}$ & $\begin{array}{l}\text { Norway; stu- } \\
\text { dents gradua- } \\
\text { ting in } 1993 \& \\
\text { 1994, average } \\
\text { period of obser- } \\
\text { vation: } 3.6 \text { yrs. }\end{array}$ & $\begin{array}{l}\text { Nationwide represen- } \\
\text { tative sample from } \\
\text { Norway's medical } \\
\text { schools }\end{array}$ & $\begin{array}{l}\text { Postal questionnaire } \\
\text { sent to medical students } \\
\text { last term of medical } \\
\text { school, at the end of } \\
\text { internship year and } \\
\text { 2-3 years later. }\end{array}$ & $\begin{array}{l}28(6.4 \%) \text { reported suicidal planning in their postgraduate } \\
\text { years. } 8 \% \text { had previous suicidal thoughts. Predictors of suicidal } \\
\text { planning were depressive symptoms and vulnerable } \\
\text { personality traits. }\end{array}$ \\
\hline $\begin{array}{l}\text { Ohtonen } \\
\text { et al., } \\
(2002)\end{array}$ & $\begin{array}{l}\text { Finland; } \\
\text { 1984-2000 }\end{array}$ & $\begin{array}{l}\text { Database of Finnish } \\
\text { Medical Association } \\
\text { covering deaths of all } \\
\text { medical doctors }\end{array}$ & $\begin{array}{l}\text { Measure: age } \\
\text { standardised mortality } \\
\text { rate }\end{array}$ & $\begin{array}{l}\text { SMR for anaesthesiologists are lower than other specialists; } \\
17 \% \text { suicide rate among anaesthesiologists compared to } 2 \% \\
\text { general population. }\end{array}$ \\
\hline $\begin{array}{l}\text { Svarsudd } \\
\text { et al., } \\
(2002)\end{array}$ & $\begin{array}{l}\text { Sweden; } \\
\text { 1993-1999 }\end{array}$ & $\begin{array}{l}\text { Survival data on } \\
26086 \text { physicians from } \\
\text { official records }\end{array}$ & $\begin{array}{l}\text { Mortality data \& } \\
\text { causes of death (for } \\
\text { deaths till 1997) }\end{array}$ & $\begin{array}{l}\text { Crude mortality rate among anaesthesiologists } 26 \% \text { lower } \\
\text { than all physicians; After adjusting for differences in age, } \\
\text { gender, anaesthesiologists } 46 \% \text { higher mortality than other } \\
\text { specialities. }\end{array}$ \\
\hline
\end{tabular}

MRR-Mortality rate ratios; PMR-Proportional mortality rate; SI-suicidal ideation, SMR-Standardardised mortality rate. 
Table 1: Continues

\begin{tabular}{|c|c|c|c|c|}
\hline $\begin{array}{l}\text { Authors } \\
\text { (Publica- } \\
\text { tion year) }\end{array}$ & $\begin{array}{l}\text { Country and } \\
\text { Study Period }\end{array}$ & Data source & Study design & Main findings \\
\hline $\begin{array}{l}\text { Aasland } \\
\text { et al., } \\
(2002)\end{array}$ & $\begin{array}{l}\text { Norway; } \\
2001\end{array}$ & $\begin{array}{l}\text { Master file of } \\
\text { Norwegian Medical } \\
\text { Association }\end{array}$ & $\begin{array}{l}\text { Survival analysis with } \\
\text { data on } 10367 \text { specia- } \\
\text { lists }=574065 \text { man-yrs. }\end{array}$ & $\begin{array}{l}\text { No difference in mortality rates between anaesthesiologists, } \\
\text { pediatricians and other specialists. }\end{array}$ \\
\hline $\begin{array}{l}\text { Aasland } \\
\text { et al., } \\
(2001)\end{array}$ & $\begin{array}{l}\text { Norway; } \\
\text { 1960-1989 }\end{array}$ & $\begin{array}{l}\text { Census data and data } \\
\text { on educational level }\end{array}$ & $\begin{array}{l}\text { Suicide rates: crude } \\
\text { and controlled for } \\
\text { age and time period }\end{array}$ & $\begin{array}{l}\text { Crude rates: Male physicians: } 47.7 . \\
\text { General population: } 22.7 \text { (males). } \\
\text { Female physicians: } 32.3 . \text { General population: } 7.7 \text { (females) }\end{array}$ \\
\hline $\begin{array}{l}\text { Hawton } \\
\text { et al., } \\
(2001)\end{array}$ & $\begin{array}{l}\text { England \& } \\
\text { Wales; } \\
\text { 1991-1995. }\end{array}$ & $\begin{array}{l}\text { NHS Doctors list of } \\
\text { doctors who died by } \\
\text { suicide; population at } \\
\text { risk based on the } \\
\text { department of health } \\
\text { manpower data }\end{array}$ & $\begin{array}{l}\text { Retrospective cohort } \\
\text { study; Measure: Suicide } \\
\text { rates calculated by } \\
\text { gender, age, speciality } \\
\text { and time period. SMR } \\
\text { adjusted for age and sex }\end{array}$ & $\begin{array}{l}\text { Suicide rate in female doctors higher than general population } \\
\text { (SMR: } 201.8 ; 95 \% \mathrm{CI}: 99.7-303.9 \text { ) and rate in male doctors less } \\
\text { than that of general population ( } \mathrm{SMR} 66.8 ; 95 \% \mathrm{Cl} 46.6,87.0 \text { ). } \\
\text { Anaesthesiologists, community health doctors, general practi- } \\
\text { tioners and psychiatrists higher rates than general medicine } \\
\text { doctors. }\end{array}$ \\
\hline $\begin{array}{l}\text { Alexander } \\
\text { et al., } \\
(2000)\end{array}$ & $\begin{array}{l}\text { U.S; } \\
1979-1995\end{array}$ & $\begin{array}{l}\text { Physician Master file } \\
\text { database }\end{array}$ & $\begin{array}{l}\text { Cohort of } 40211 \text { inter- } \\
\text { nists frequency matc- } \\
\text { hed to } 40242 \text { anaest- } \\
\text { hesiologists by gender, } \\
\text { decade of birth and } \\
\text { citizenship; Measure: } \\
\text { SMR }\end{array}$ & $\begin{array}{l}\text { SMR for all physicians were below } 1.0 \text { except for suicide. All } \\
\text { cause mortality ratios, risks of death due to cancer and heart } \\
\text { disease were similar between both groups; Anaesthesiologists } \\
\text { had increased risk of death from suicide [Rate ratio: } 1.45 \\
\text { (1.07-1.97)], drug related death, death from cerebrovascular } \\
\text { disease and other external causes compared to internists. }\end{array}$ \\
\hline $\begin{array}{l}\text { Hem } \\
\text { et al., } \\
(2000)\end{array}$ & $\begin{array}{l}\text { Norway; } \\
1993\end{array}$ & $\begin{array}{l}\text { Members of the } \\
\text { Norwegian Medical } \\
\text { Association }\end{array}$ & $\begin{array}{l}\text { Questionnaire on sui- } \\
\text { cidal thoughts sent to } \\
\text { the members; Response } \\
\text { rate : } 72 \%\end{array}$ & $\begin{array}{l}\text { Lifetime prevalence ranged from } 51.1 \% \text { for feelings of worth- } \\
\text { lessness to } 1.6 \% \text { for suicidal attempt. These thoughts were not } \\
\text { attributed to working conditions. }\end{array}$ \\
\hline $\begin{array}{l}\text { Juel } \\
\text { et al., } \\
\text { (1999) }\end{array}$ & $\begin{array}{l}\text { Denmark; } \\
1973-1992\end{array}$ & $\begin{array}{l}\text { Membership register } \\
\text { of Danish Medical } \\
\text { Association }\end{array}$ & $\begin{array}{l}\text { Cause specific mor- } \\
\text { tality in NHS hospital } \\
\text { consultants }\end{array}$ & $\begin{array}{l}\text { Doctors' mortality lower than general population. } \\
\text { SMR for suicide among female doctors: } 1.7(95 \% \mathrm{Cl}=1.1-2.5) \text {, } \\
\text { male doctors: } 1.6 \text { ( } 95 \% \mathrm{Cl}=1.4-1.9) \text {. Excess suicide rates due to } \\
\text { poisoning. }\end{array}$ \\
\hline $\begin{array}{l}\text { Carpenter } \\
\text { et al., } \\
\text { (1997) }\end{array}$ & $\begin{array}{l}\text { UK; } \\
1962-1992\end{array}$ & $\begin{array}{l}\text { Department of Health } \\
\text { records and follow up } \\
\text { through NHS central } \\
\text { register }\end{array}$ & $\begin{array}{l}\text { Measure: SMR and Rate } \\
\text { ratios for comparison } \\
\text { with rates in all } \\
\text { consultants }\end{array}$ & $\begin{array}{l}\text { Death rates from accidental poisoning among male consul- } \\
\text { tants significantly higher than general population (SMR 227), } \\
\text { two fold increase death from accidental poisoning mostly } \\
\text { due to barbiturates; death from injury and poisoning in female } \\
\text { consultants } 80 \% \text { higher than women; Excess of suicide in } \\
\text { female anaesthesiologists (SMR 405). }\end{array}$ \\
\hline
\end{tabular}

MRR-Mortality rate ratios; PMR-Proportional mortality rate; SI-suicidal ideation, SMR-Standardardised mortality rate.

Nyssen and colleagues (2008) believe that it is the long-term burnout more than the stress that causes significant problems for most anesthesiologists.

Anesthesiologists seem to encounter three different forms of difficulties in their practice: complex medical conditions, work overload and difficult ethical decisions (Larsson et al., 2007). Seely (1996) describes anesthesia as a stressful specialty. Predisposing factors to chronic stress in anesthetic practice are long and irregular working hours, frequent night calls leading to sleep deprivation (Alexander et al., 2000; AAGBI, 1997) need for uninterrupted vigilance (Alexander et al., 2000), feeling powerless to control the situation at work and in interaction with the surgeons: unpredictable emergency work alongwith working over limits to achieve targets and time pressure (AAGBI, 1997). Anesthesiologists work in isolation, especially those in private practice. 
Practising in isolation as well as not sharing concerns and stresses can potentially affect concentration and clinical judgment leading to errors (Kam et al., 1997). The issues with time management are: considerable overtime, difficulty in getting a break or time for non-clinical tasks, frequent changes in work during the day and the risks taken as a consequence of unplanned tasks (Gaba et al., 1994). There is often a need to make a rapid but safe decision in critical situations (Larsson, et al., 2010). This can occasionally force anesthesiologists to deviate from standard safety guidelines.

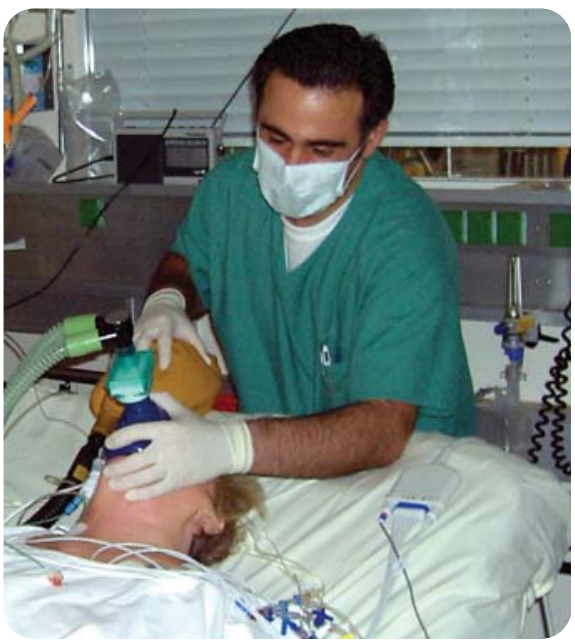

Trainee anesthesiologists also perceive a feeling of insufficiency and loneliness due to the high demands of the training and difficulty of their role (Larson et al., 2006). Out of the trainees at different levels, third year trainees experience higher stress due to the sudden increase in responsibility of managing cases on their own (Gaba et al., 1994). Bias and discrimination amongst the peers and consultants is also the cause of stress in female registrars (Greenwell, 2000). According to Swanson and colleagues (2003), among female doctors, occupational stress such as dealing with sufferers, issues of death and work-life balance have been suggested as risk factors for suicide. The perception of stress also depends on the dynamic interaction of their personal, social and biological resources that can act as a buffer against high job demands (Nyssen, et al., 2008).

\section{Depression}

Depression is considered to be the major risk factor for suicide in doctors. It can have physical, family, professional and patient-safety consequences (Rose et al., 2010). The difference between other clinical specialities and anesthesia is that, often, the valuable service provided by anesthesiologists goes unrecognised and unappreciated in comparison to other medical specialists, especially surgeons, due to the brief contact period with their patients. This can increase the frustration with their careers among anesthesiologists. Data on the prevalence of depression among anesthesiologists are not available (Rose et al., 2010), although the rate in physicians is almost comparable to that in general population (Center et al., 2003).

\section{Miscellaneous factors}

Other predisposing factors to depression and suicide among medical practitioners in general, are career change as at the beginning of the training or retirement planning that involves a lot of adjustments, poor mental health, family history or personal history of psychiatric illness, sexual abuse, domestic violence or alcohol abuse (Frank et al., 1999), marital stress and financial losses (Swanson et al., 2003), bereavements, personal illness or job loss, life styles that doctors are expected to maintain (AAGBI, 1997) and fear of litigation due to medical negligence.

Reluctance to seek professional help and self-prescription practices are significant issues among medical practitioners (Swanson et al., 2003). The reluctance could also be due to the fear of negative consequences on their practice, such as loss of medical board registration, insurance issues, problems with job seeking, loss of respect among colleagues and breach of confidentiality. The Type A personality is seen more often among physicians along with status insecurity, anxiety and time urgency, all of which predispose them to stress (Thomas et al., 2006). The majority of physicians who died by suicide had psychiatric disorders according to a study by Hawton and colleagues (2004). Pre-existing affective disorders among susceptible physicians play a more important role than occupational stressors in predisposing them to suicide (Center et al., 2003).

\section{Discussion}

The existing studies do not necessarily give a true picture of the problem since there could be underreporting of events, publication bias, a variety of definitions for suicide and cases where it is difficult to pinpoint the accurate cause of death (Lindeman et al., 1996). There could be loss to follow up in an observational study due to the residents moving from one hospital to another (Fleisher, 2000). Also the information could have been gathered mainly from the treatment programs that cater to physicians who have confirmed drug addiction (Lutsky et al., 1994). From the literature, it was not certain if anesthesiologists have highest suicide rate as compared to other specialties, but it was evident that these specialists have a high risk of substance misuse that along with depression are well-established risk factors of suicide.

\section{Strategies to prevent suicides among anesthesiologists}

Suicidal behavior can be managed and suicides may be prevented if appropriate measures are implemented at an early stage. Anesthetic staff could be educated to recognize and treat depression and substance misuse among their colleagues and patients respectively, so that treatment can be initiated early enough. General practitioners may be lacking knowledge about depression or fail to screen patients with depression that could lead to non-treatment resulting in suicide (Mann et al., 2005). There should be formal departmental policies to deal with the affected individuals in a confidential manner. The relevant college, organisation or work place should provide psychological, professional and financial support to the physicians, who have been identified as drug users and those who have attempted suicide. They are likely to encounter difficulties in reestablishing their practice. 
Means restriction has been described as an important measure to prevent suicides (Mann et al., 2005). Departmental staff can identify at risk individuals and can act as organizational gatekeepers, thereby enabling early detection and appropriate referral (Mann et al., 2005). Precautions like strict recordkeeping for drugs in the operating theatres and wards, can restrict the access to narcotic drugs and improve accountability of the doctor or other medical staff. There could be a formal screening program for depression and suicide risk on a regular basis. The organisation could provide specialists' counselling and mentoring for the trainees (Nyssen et al., 2003) and the consultants in need of help and support. Anesthetic training program should involve promoting coping strategies for anesthesiology trainees (Larsson et al., 2010). Educating trainees about the consequences of substance abuse may increase the number of anesthesiologists seeking treatment (Rose et al., 2010). Anesthesiologists should learn to prioritize between tasks and delegate jobs to others when there is work overload (Larsson et al., 2010). Departmental meetings to discuss incidents and major misadventures in the operating theatre with the goal to provide support to the involved anesthesiologist should be held regularly or on a as-per-need basis (Nyssen et al., 2003). Departmental protocols on reporting of suspected alcohol or drug abuse must be followed (Thomas et al., 2006). Trainees and consultants should be encouraged to enroll in crisis management-courses to improve communication and problem solving skills. Anesthetic department and theatre management team should consider changing the operating theatre environment to remove the sources of stress (Nyssen et al., 2003).

\section{Conclusion}

Anesthesiology is a medical speciality with multiple predisposing risk factors for suicide, mainly job stress and easy access to means for suicide as discussed in the article. The studies reporting the higher risk of suicide amongst anesthesiologists compared to other physicians may be subject to a lot of measurement errors and biases, hence may not give accurate representation of the problem. Hence the applicability of the results from these not-so-recent studies may be limited. Nevertheless, it appears that the true extent of the problem is still unknown. Many major organisations have programs to assist doctors with depression and personality disturbances. Every doctor should act responsibly and not ignore the early warning symptoms in themselves and their colleagues to seek appropriate support in order to make best use of the existing programmes. Further loss to medical community from this problem should not happen.

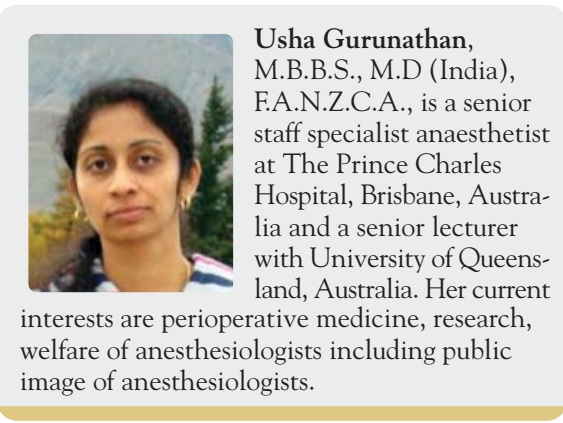

\section{References}

Aasland, O.G., Ekeberg, O., Schweder, T. ( 2001). Suicide rates from 1960-1989 in Norwegian physicians compared with other educational groups. Soc Sci Med. 52, 259-265.

Aasland, O.G., Hem E., Haldorsen, T., Ekeberg, O. (2011). Mortality among Norwegian doctors 1960-2000. BMC Public Health, 11, 173

Aasland, O.G.( 2002). Mortality of anesthesiologists, pediatricians, and other specialists in Norway. Acta Anaesthesiol Scand, 46, 1200-1202.

Alexander, B.H., Checkoway, H., Nagahama, S. I., \& Domino, K.B.(2000). Cause-specific mortality risks of anesthesiologists. Anesthesiology, 93, 922-30. Association of Anaesthetists of Great Britain and Ireland. (1997). Stress in Anaesthetists. 21, Portland Place, London.

Berry. A., \& Fleisher, L. (2000). Cause specific mortality risks of anesthesiologists: New Evidence for the existence of old problems. (Editorial). Anesthesiology, 93(4), 919-921.

Booth, J.V., Grossman, D., Moore, J., Lineberger, C., Reynolds, J.D., Reves, J.G., \& Sheffield, D. (2002) Substance abuse among physicians: A survey of academic anesthesiology programs. Anesth Analg. 95, 1024-30.

Bryson, E.O., \& Hamza, H.( 2011). The drug seeking anaesthesia care provider. Int Anesthesiol Clin, 49(1), 157-71.

Bryson, E.O., \& Silverstein, J.H. (2008). Addiction and substance abuse in anesthesiology. Anesthesiology, 109(5), 905-17.
Carpenter, L.M., Swerdlow, A.J., \& Fear, N.T (1997). Mortality of doctors in different specialities: Findings from a cohort of 20000 NHS Hospital consultants. Occup Environ Med, 54(6), 388-395.

Center, C., Davis, M., Detre ,T., Ford, D.E., Hansbrough, W., endin, H., Laszlo, J., Litts, D.A., Mann, J., Mansky P.A., Michels, R., Miles, S.H. Proujansky, R., Reynolds, C.F. \&Silverman, M.M. (2003). Confronting depression and suicide in physicians: a consensus statement. JAMA, 289, 3161-6.

Chiron, B., Michinov, E., Olivier-Chiron, E., Laffon M. \& Rusch, E. ( 2010). Job Satisfaction, life satisfaction and burnout in french anaesthetists. J Health Psychol. 15(6), 948-958.

Collins, G.B., McAllister, M.S., Jensen, M. \& Gooden, T.A.(2005). Chemical dependency treatment outcomes of residents in anesthesiology: results of a survey. Anesth Analg. 101(5), 1457-62.

Dyrbye, L.N., Thomas, M.R., Massie F.S., Power, D.V., Eacker, A., Harper, W., Durning, S., Moutier, C., Szydlo, D.W., Novotny, P.J., Sloan, J.A., Shanafelt, T.D. (2008). Burnout and Suicidal Ideation among U.S. Medical Students. Ann Intern Med, 149, 334-341.

Frank, E. \& Dingle, A.D. (1999). Self-reported depression and suicide attempts among U.S. Women Physicians. Am J Psychiatry, 156, 1887-1894.

Gaba, D.M., Howard, S.K., Jump, B. (1994). Production pressure in the work environment. California anesthesiologists' attitudes and experiences. Anesthesiology, 81, 488-500.

Greenwell, S.K.(2000). Stress in trainee anaesthetists. Anaesthesia, 55, 203-5.

Gold, M.S., Byars, J.A., Frost-Pineda, K. (2004) Occupational exposure and addictions for physicians: Case studies and theoretical implications. Psychiatr Clin North Am 27, 745-53.

Hawton, K ., Clements, A., Sakarovitch, C., Simkin, S., \& Deeks, J.J. (2001). Suicide in doctors: a study of risk according to gender, seniority and specialty in medical practitioners in England and Wales,1979-1995. J Epidemiol and Community Health, 55, 296-300.

Hawton, K., Malmberg, A., \& Simkin, S. (2004). Suicide in doctors; A psychological autopsy study. J Psychosom Res, 57(1), 1-4.

Hawton, K., \& van Heeringen, K.(2009). Suicide. Lancet, 373, 1372-81.

Hem, E., Grønvold, N.T., Aasland, O.G. \& Ekeberg, $\varnothing$. (2000). The prevalence of suicidal ideation and suicidal attempts among Norwegian physicians. Results from a cross-sectional survey of a nation-wide sample. Eur Psychiatry. May;15(3), 183-9.

Hem, E., Haldorsen, T., Aasland, O.G., Tyssen, R., Vaglum, P., \& Ekeberg, O. (2005). Suicide rates according to education with a particular focus on physicans in Norway. Psychol Med. 1960-2000. 35, 873-880.

Kam, P.C.A. (1997). Occupational stress in anaesthesia. Anaesth Intens Care 1997;25, 686-690.

Katz JD. (2004). Do anesthesiologists die at a younger age than other physicians? Age-adjusted death rates. Anesth Analg, 98, 1111-3.

Kinzl, J.F., Traweger, C., Trefalt, E., Riccabona, U. \& Lederer, W.(2007). Work stress and gender-dependent coping strategies in anesthesiologists at a university hospital. J Clin Anesth, 19, 334-8. Jenkins, R. \& Singh, B.(2000). General population strategies of suicide prevention. In the International Handbook of Suicide and Attempted Suicide (eds K Hawton \& K van Heeringen). John Wiley \& Sons. 
Juel, K., Mosbech, J., \& Hansen, E.S. (1999). Mortality and causes of death among Danish medical doctors 1973-1992. Int J Epidemiol. 28:456-460.

Larsson, J., Rosenqvist, U. \& Holmström, I. (2006). Being a young and inexperienced trainee anaesthetist: a phenomenological study on tough working conditions. Acta Anaesthesiol Scand, 50, 653-8.

Larsson, J., \& Sanner, M. (2010). Doing a good job and getting something good out of it: on stress and well-being in anaesthesia. British Journal of Anaesthesia, 105(1), 34-7.

Larsson, J., Rosenqvist, U. \& Holmström, I. (2007). Enjoying work or burdened by it? How anaest-hetists experience and handle difficulties at work: a qualitative study. Br J Anaesth, $99,493-8$.

Lindeman, S., Laara, E., Hakko, H., Lonngvist, J. (1996). A systematic review on gender-specific suicide mortality in medical doctors. British Journal of Psychiatry, 168, 274-279.

Lindfors, P.M., Meretoja, O.A., Luukkonen, R.A., Elovainio, M.J., \& Leino, T.J. (2009). Suicidality among Finnish anaesthesiologists. Acta Anaesthesiologica Scandinavica, 53(8), 1027-1035. Lutsky, I., Hopwood, M., Abram, S.E., Cerletty, J.M., Hoffman, R.G., \& Kampine, J.P. (1994). Use of psychoactive substances in three medical specialities: Anaesthesia, medicine and surgery. Can J Anaesth, 41, 561-7.

Mann, J.J., Apter, A., Bertolote, J., Beautrais, A., Currier, D., Haas, A., Hegerl, U., Lonnqvist, J., Malone, K. Marusic, A., Mehlum, L., Patton, G., Phillips, M., Rutz, W., Rihmer, Z., Schmidtke, A., Shaffer, D., Silverman, M. Takahashi, Y., Varnik, A., Wasserman, D., Yip, P. $\&$ Hendin, H. (2005). Suicide prevention strategies: a systematic review. JAMA, 294, 16, 2064-74.

Meltzer, H., Griffith, C., Brock, R., Rooney, C., Jenkins, R. (2008). Patterns of suicide by occupation in England and Wales: 2001-2005. Br J Psychiatry, 168, 274-279.

Nyssen, A.S., Hansez, I., Baele, P., Lamy, M. \& De Keyser, V. (2003). Occupational stress and burnout in anaesthesia. Br J Anaesth, 90, 333-7.

Nyssen, A.S., \& Hansez, I. (2008). Stress and burnout in anaesthesia. Current opinion in anaesthesiology, 21, 406-11.

Ohtonen, P., Alahuhta, S. (2002). Mortality among Finnish anesthesiologists from 1984-2000. Acta Anaesthesiol Scand, 46, 1196-1199.

Rose, G.L., \& Brown, R.E Jr. (2010). The impaire anesthesiologist: not just about drugs and alcohol anymore. J clin Anesth, 22 (5); 379-84

Schernhammer, E.S. \& Colditz, G.A.(2004). Suicide rates among physicians: A quantitative and gender as sessment (meta-analysis). Am J Psychiatry, 161, 2295-2302.

Seeley, H.F. (1996). The practice of anaesthesia - a stressor for the middle-aged? Anaesthesia, 51(6), 571-4.

Shanafelt, T.D., Balch, C.M., Dyrbye, L., Bechamps, G., Russell, T., Satele, D., Rummans, T., Swartz, K. Novotny, P.J., Sloan, J., \& Oreskovich, M.R (2011) Special report: suicidal ideation among American Surgeons. Arch Surg, 146(1), 54-62.

Svardsudd, K., Wedel, H., \& Gordh, T.Jr. (2002). Mortality rates among Swedish physicians: a populationbased nationwide study with special reference to anesthesiologists. Acta Anaesthesiol Scand, 46(10) 1187-1195.

Swanson, S.P., Roberts, L.J., \& Chapman, M.D. (2003). Are anaesthetists prone to suicide? A review of rates and risk factors. Anaesth Intensive Care, 31, 434-445.

\section{Ny doktorgrad i suicidologi - NSSF gratulerer!} Ph.d. Cand.med. Arne Thorvik disputerte 14. april 2011

\section{"Suicid som etisk fenomen - teoretiske og empiriske perspektiver"}

\section{Sammendrag: Verden sett med suicidale øyne}

Lege spes psykiatri Arne Thorvik har i avhandlingen Suicid som etisk fenomen - teoretiske og empiriske perspektiver på bruk av tvang $i$ psykisk helsevern fors $\varnothing \mathrm{kt}$ å rekonstruere suicidale menneskers opplevelse av sin situasjon. Generelt har en stor del av selvmords-

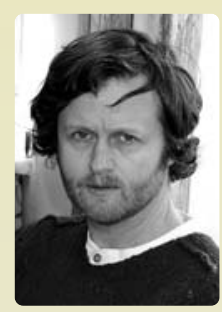
forskningen tatt for seg statistisk materiale. Det finnes i mindre grad kvalitative studier som belyser hvordan suicidale tenker og opplever verden. Særlig er dette tilfellet når det gjelder psykotiske mennesker med suicidproblematikk. Thorvik har gjort dybdeintervjuer av 20 psykotiske og 20 ikke-psykotiske informanter som nylig var vurdert som selvmordstruede (tilknyttet Psykiatrien i Vestfold). Følgende fellestrekk ble funnet:

Informantene beskrev en suicidal prosess, der tanken på suicid ble gradvis sterkere, og der opplevelsen av egen kontroll ble suksessivt mindre. Dette var ledsaget av en umiddelbar forestilling om "ikke å ha noen fremtid". Flertallet (også informanter som til vanlig hadde religiøst livssyn) var lite opptatt av dødens innhold, annet enn at den representerte et fravær av smerte.

Av de psykotiske informantene fortalte halvparten at psykotiske opplevelser hadde spilt en avgjørende rolle.

Informantenes etiske refleksjon rundt fenomenet suicid viste innslag av så vel konsekvensetikk, dydsetikk og religiøs tenkning. Etisk tenkning ble imidlertid endret med den suicidale prosessen, og premissene for etisk analyse ble svekket.

Et vesentlig funn var at mange poengterte at suicidalitet vanskelig kan drøftes med nærstående, men med fagpersoner som er bundet av profesjonelle standarder. Ambivalens og en perifer forestilling om å trenge hjelp var til stede. I ettertid hadde mange aksept for nødvendigheten av ivaretakelse $\mathrm{i}$ form av tvangsinnleggelse.

I tillegg til det empiriske materialet inneholder avhandlingen en teoretisk gjennomgang av filosofiske nøkkelposisjoner i forståelsen av suicid. Et eget kapittel tar for seg psykologiske teorier, og drøfter spesielt hvorvidt psykoanalytisk tradisjon er å forstå som en fenomenologi, som er den tilnærmingen som avhandlingen i sum er basert på.

Thomas, I. \& Carter, J. A. Occupational hazards of anaesthesia. (2006). Contin Educ Anaesth Crit Care Pain, 6 (5), 182-187.

Tyssen, R., Hem, E., Vaglum, P., Grønvold, N.T. \& Ekeberg, $\varnothing$. (2004). The process of suicidal planning among medical doctors: predictors in a longitudinal Norwegian sample. J Affect Disord, 80, 191-198.

Tyssen, R., Vaglum, P., Grønvold, N.T., Ekeberg, Ø. (2001). Suicidal ideation among medical students and young physicians: a nationwide and prospective study of prevalence and predictors. J Affect Disord, 64, 69-79.
Weeks, A.M., Buckland, M.R., Morgan, E.B., Myles, P,S.(1993). Chemical dependence in anaesthetic registrars in Australia and New Zealand. Anaesth Intensive Care, 21,151-5.

Wischmeyer, P.E., Johnson, B.R., Wilson, J.E., Ding mann, C., Bachman, H.M., Roller, E., Tran, Z.V., Hent horn T.K. (2007). A survey of propofol abuse in academic anesthesia programs. Anesth Analg, 105(4), 1066-71. 